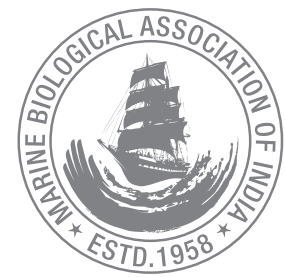

\title{
An appraisal of trawl fisheries of India with special reference on the changing trends in bycatch utilization
}

\author{
A. P. Dineshbabu*, E. V. Radhakrishnan, Sujitha Thomas , G. Maheswarudu, P. P. Manojkumar, \\ Shoba Joe Kizhakudan, S. Lakshmi Pillai, Rekhadevi Chakraborty, Josileen Jose, P. T. Sarada, \\ Paramita Banerjee Sawant', K. K. Philipose, V. D Deshmukh, J. Jayasankar, Subhadeep Ghosh, \\ Mohamed Koya , G. B Purushottama and Gyanaranjan Dash \\ Central Marine Fisheries Research Institute, Kochi, Kerala - 682 018, India. \\ 1 Central Institute of Fisheries Education, Panch Marg, Andheri (W) Mumbai, India- 400061. \\ *Correspondence e-mail: dineshbabuap@yahoo.co.in
}

Received: 25 Jul 2013, Accepted: 15 Jan 2014, Published: 30 Jan 2014

Original Article

\begin{abstract}
Trawl fisheries sector account more than $50 \%$ of the marine fisheries production of India. Annual average fish landing from trawlers was 17, 21, 000 t (2008-2011), which formed around $51 \%$ of the marine fish landing of the coast. In this about $51 \%$ of the catch was contributed by the west coast and remaining by the east coast of India. Recent studies of the trawl fishery in India have shown that incidental catches/low value bycatch (LVB) landing and utilization has increased over the period of time. The present study is based on the data collected from major trawl landing centres along the coast of India during the period 2008-2011. The estimated landing of low value bycatch (LVB) in trawl fisheries, increased from $14 \%$ in 2008 to $25 \%$ in 2011, which is reflected as reduction in discard volume by trawlers. On an average the highest quantity of LVB landed was in Veraval (50,000 t) and in Mangalore, LVB landing increased from $3 \%$ in (3000 t) in 2008 to $26 \%(12,000 \mathrm{t}$ ) in 2011.In Mumbai, the percentage of trash fish landed remained around 5\% during the study period. In Calicut, the LVB landed in 2011 contributed $26 \%$ to the total landings by the trawl. In Kochi, Kerala the total LVB landed in 2011 was 1,992 $\mathrm{t}$ forming $7.2 \%$ of the total landing. In Chennai, Tamilnadu, the LVB landing which was $13 \%$ in 2008 increased to $17 \%$ in 2011, while in Visakhapatanam, Andhra Pradesh, LVB landing showed a steady increase from $2 \%$ in 2008 to $21 \%$ in 2011 . The landing centre price for LVB showed an increasing trend due to increased demand for trash fish for the production of fish meal and fertilizer. The dominance of finfishes in LVB found to increase the value of LVB and the value realized for 30,000 $t$ of LVB in
\end{abstract}

Mangalore in 2011 ( Rs.280 million) was more than that realized for $50,000 \mathrm{t}$ of LVB in Veraval (Rs.200 million). A disturbing trend observed from the studies in Mangalore was that, the sardines in trash fetches higher price in some seasons (upto Rs.16/kg) compared to a lower price when landed in fresh form, and the percentage of sardines in LVB is found to be very high $(24 \%$ in 2010$)$. This trend may cause a severe threat to the protein availability to the rural poor. Looking at the trend of trawl landing during 2008-2012, it is seen that even though the trawl landing showed an increase over the period of time, the edible portion of the trawl landing did not show any significant increase rather showing general declining trend. Study on the bycatch from different centres along the coast of India showed that as many as 237 species / groups of marine fauna with juveniles of commercially important fishes were landed as LVB. Increase in utilization of LVB (which was discarded earlier) from trawl fishery, a trend which is market driven and its implication on the ecosystem and marine fisheries production of the country is discussed in this paper.

Keywords: Trawl fishery, India, low value bycatch, discards, juvenile fishery.

\section{Introduction}

Trawling has contributed to increased marine fish production and has led to its widespread adoption by many countries. In India, trawlers have contributed major part of the total 
marine fish production (Srinath, 2003). But in recent years due to its irrational operation, trawling is considered as a major human caused physical and ecological disturbance on the world's continental shelves causing physical destruction of marine ecosystems (Jennings and Kaiser, 1998). Its extensive combing of sea bottom is causing widespread damage to marine biota and urgent need for regulation in fishing is required so that fish production can be made sustainable (Devaraj and Vivekanandan, 1999). Trawlers generally discard non-commercial species (Van Beek, 1998) but ever since the fish protein from sea became an important raw material for feed industries, the percentage of discards has come down substantially and low value bycatch from trawlers are used extensively to feed livestock/fish, either directly or through reduction to fish meal/oil (Simon et al., 2005). The demand for fish meal has increased intensely with aquaculture development, which encouraged trawler operators to bring all the catch to the shore as Low value bycatch (LVB). In India, the quantity of fish meal used for shrimp culture and Indian carp culture in 2001 was $41,000 \mathrm{t}$ and 200,000 t., respectively (Simon et al., 2005). Considering the trend is likely to continue, an estimated 270,000 tonnes of low value/trash fish is expected to be required to produce fish meal for aquaculture in India by the end of the decade and this demand in turn would put increased pressure on ecosystem (FAO, 2010). The economics of LVB marketing was studied by Aswathi et al. (2011) and observed that there is an urgent need for comprehensive analysis and estimation of bycatch and discards from trawlers from all coastal states of the country, for developing macro-level policies in fisheries management.

In the tropical fishery, when a trawl net is operated, many species which have demand either for edible purpose and some for non-edible purpose caught. Hence, the concern of the trawler operator will be whether it would be economically viable to bring the species in a preserved condition to the landing centre. Practically these criteria decide which is to be landed for edible purpose in the best possible preservation, which is to be brought to shore without much preservation to land as "trash" and which is to be discarded for which bringing to the shore in any form may not fetch any additional return. The studies related to Low value bycatch (LVB) and discards have to be approached with the economic aspect in mind. Economically all fishes landed in fresh or trash form is bringing additional economic return to fishermen. In the present study, the term 'LVB' is used for those fishes landed for non-edible purpose (trash) without much preservation and not the "low value fishes" landed in preserved condition for edible purpose. The present study is particularly aimed at estimating the quality and quantity of landed 'low-value bycatch' and discards by commercial trawlers at major landing centres and to evaluate the potential bycatch problems in marine fisheries management of India. Study also aims at studying impact of trawl fishery on marine fauna especially, the impact on the juveniles of commercially important fishes, so that management options in trawl fishery for sustaining marine fish production can be formulated and suggested by estimating the extent of the problem.

\section{Material and methods}

All India trawl landing data from all maritime states were estimated using stratified multi-stage random sampling method (Srinath et al., 2005) during 2007-2012. For the purpose trawl fishery data from all major and minor trawl landing centres were estimated. To get the catch and bycatch scenario in trawl fisheries, trawl catch from major fishing harbours of India(Fig.1), namely, Veraval, Mumbai, Karwar,

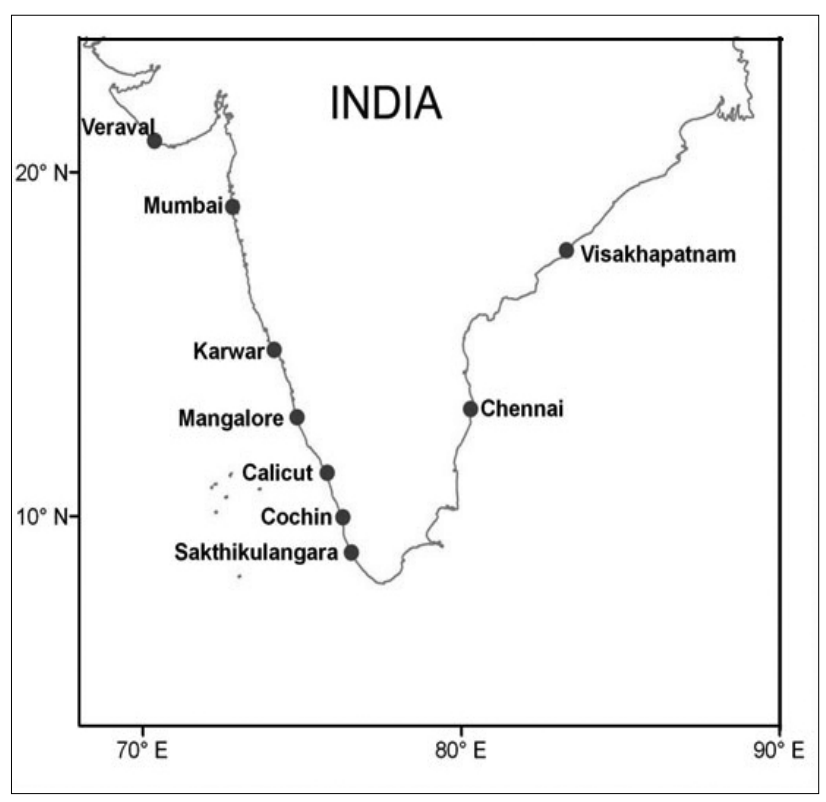

Fig. 1. Location map of trawl centres along Indian coast

Mangalore, Calicut, Cochin, Sakthikulangara, Chennai, and Visakhapatnam were collected and catch and bycatch were analyzed to species level. Data collection was done twice a week. It was estimated that these fisheries harbors selected for the study together contribute $33 \%$ of the trawl landings of the country (more than $50 \%$ of the multi-day trawl landing) during 2007-2012. The landing has been classified as those landed for "edible uses" and the rest landed as low value bycatch (LVB) for non-edible purpose. Monthly estimates of catch, effort and species composition of commercial catch and trash were made based on these data (Srinath et al., 2005). Along with catch data, the market price for the catch and bycatch also were collected from each landing centre. An unsorted portion of non-edible landed bycatch (LVB) was analysed to 
species level to understand the species composition and the juvenile composition in the sample. Data on onboard catch, bycatch and discard were collected from selected commercial trawlers operated from Veraval, Mangalore, Calicut and Visakhapatnam on daily basis. During the initial phase of data collection (2007) the researchers participated in the cruise and selected crews were trained in fishing and fishery data collection and also in sampling and preservation of the bycatch. Regularly an unsorted portion of catch, which is normally discarded by fishermen, was collected and labelled by trained crews of the trawler. The samples were preserved in ice and stored in fish-hold. The samples were collected from the crews after each cruise andbrought to the laboratory as fresh as possible to identify the fishes at species level. Qualitative and quantitative analyses of the samples were made in the laboratory. The following terms and definitions (Costa et al., 2008) are used in this paper: 'total catch' is the quantity of all species brought onboard; 'landed catch' is part of the total catch that has economic value (i.e. the quantity commercial fish for edible use and low valued species for non-edible purpose); 'total bycatch' is the portion of the total catch, which may be retained if it has commercial value (LVB) or discarded at sea if it is not used for any purpose (discarded bycatch). The terms "LVB used in this paper represents the non-edible portion of landed bycatch and the term 'discard" for the discarded portion of bycatch.

\section{Results}

\section{Trawl fisheries}

From all the selected major landing centres both single and multi-day trawlers were operated. Single day trawlers leave the fishing port early morning and return by afternoon. The multiday trawlers operate for more than one night extending up to 9 to 13 days. Though trawl is a non-selective gear there is a targeted fishery in each season. Major targets are shrimps, cephalopods and high valued demersal fishes. High opening bottom trawls, midwater trawls and semipelagic trawls are operated which target demersal, semipelagic and pelagic fishes. In the early years of trawling the depth of operation was limited to 30 to $50 \mathrm{~m}$ with the voyage time of 5 to 8 hours. The entire catch was brought to the shore and similar scenario is continuing in single day operating vessels in many landing centres. In the case of multi-day operating vessels generally entire catch was not brought to shore if the catch is more than the fish hold capacity. It was observed that the comparative economic viability of bringing the fish in preserved form or in non-preserved form depends on the demand for the species in the landing centre.

The estimated all India trawl landing show an increasing trend during the period of study (Fig.2). Average all India trawl landing for the period 2008-2011 is $17,21,000 \mathrm{t}$ with a maximum of $20,27,000 \mathrm{t}$ in 2011 which formed $51 \%$ of the total marine fish landing in the country. The west coast of India contribute $51 \%$ of the catch. Gujarat State accounted for $20 \%$ of the trawl landing of the country of which $42 \%$ is landed at Veraval fisheries harbor. Likewise, Karnataka account for $11 \%$ of the country's trawl landing of which $54 \%$ landed in Mangalore fisheries harbor. On the east coast of India, Andhra Pradesh accounted for $9 \%$ of Indian trawl landing of which Visakhapatnam fisheries harbor accounted for $51 \%$. It was observed that even though the total landing by trawlers showed a steady increase during 2008-2011, similar increase was not reflected in the edible portion of the landing, which was fluctuating around 3 lakh t. The nonedible portion of the landing steadily increased from 50,000 $t$ in 2008 to one lakh $t$ in 2011 (Fig. 3). The LVB at different

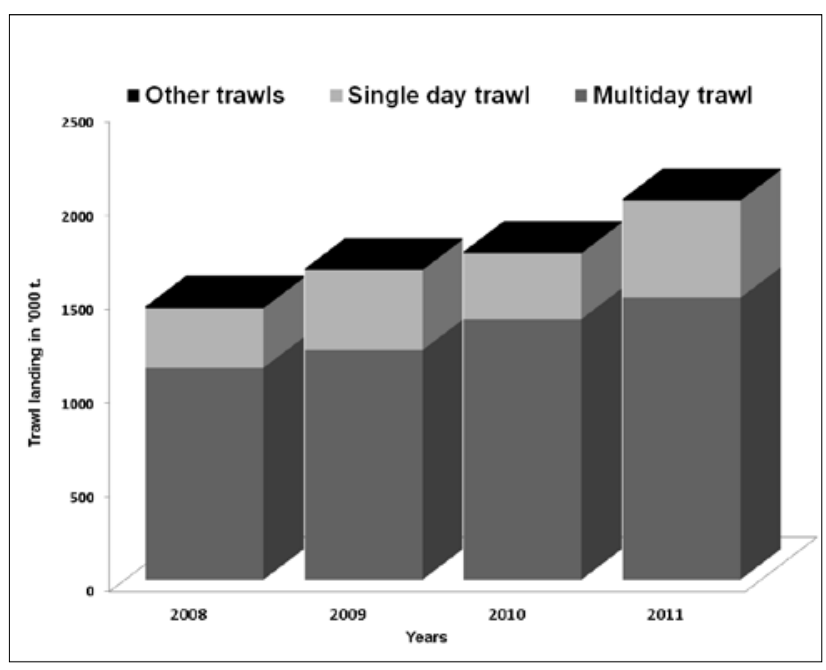

Fig. 2. All India trawl landings during 2008-2011

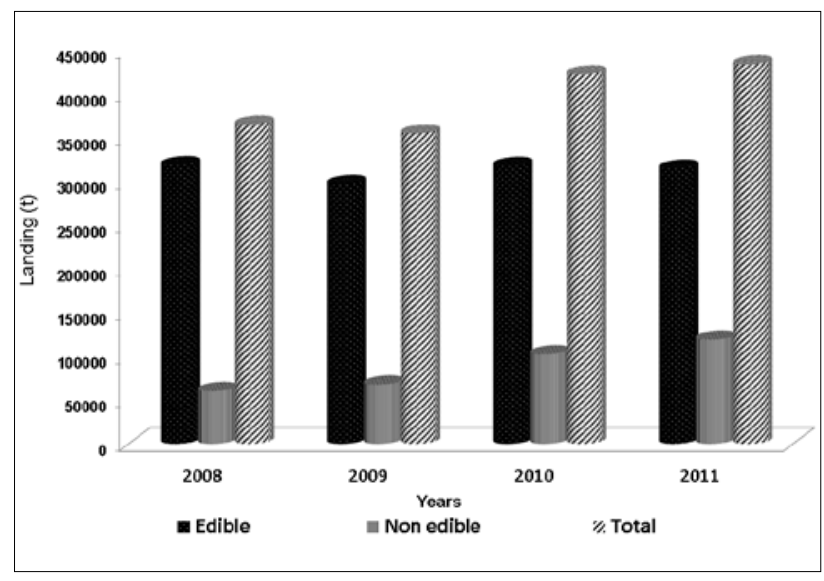

Fig.3. Quantity of edible and non-edible fish landings in major trawl fishing centres of Indian coast 
centres increased from $16 \%$ of the total catch in 2008 to $27 \%$ in 2011.

\section{Discarded bycatch}

Estimation of the percentage of discards was made from the onboard samples collected from the trawlers at Veraval, Mangalore, Calicut and Visakhapatnam fisheries harbours. In 2008, the estimated discard constituted $18 \%$ of the total trawl catch at Mangalore, which came down to $6 \%$ in 2011, whereas in Calicut the discarded catch which was $15 \%$ of the total trawl catch came down to $4 \%$ in 2011. At Veraval, in most of the season, the entire bycatch was landed by trawlers, as there was no restriction of the landing of trash in any form of deterioration. However by the on-board data collected from trawlers of showed that from August to December, the LVB caught is discarded and the discard percentage in 2011 was estimated at $10 \%$ of the total trawl catch. In Visakhapatnam the discarded catch was $22 \%$ and the percentage of discard remained the same during the period of study. In Mumbai $15 \%$ of the bycatch was presumed to be discarded since there was restriction on trash fish landing in deteriorated form and the average trash landing was only $7 \%$ of the total trawl landing. In Chennai, reported discard was very nominal (1\%) (Fig. 4).

\section{Low value bycatch (LVB) landing}

The total trawl catch, landing pattern of edible catch, nonedible LVB and discarded by catch at different trawl centres of Indian coast is given in the Fig.3. At Veraval, it is a regular trend to land most of the fishes caught by trawlers and the LVB landing during the study showed a steady increase from 24\% to $33 \%$. At Veraval fisheries harbor, a very efficient market chain exists for the LVB which encourages trawl operators to bring as much trash as possible for landing. Onboard participatory studies conducted during 2011 revealed that during the year, $10.44 \%$ of the catch was discarded at Veraval during the monsoon and post monsoon months (August to December), when the demand for the trash fish is loo low due to erratic weather conditions. This was the general trend during the earlier years also but on introduction of modern technologies in fishing, the speed for the trawlers has increased and often the catches were more than the fish hold capacity. The trash landing at Veraval was more than $50,000 \mathrm{t}$ in 2011. In major landing centres of Mumbai, the percentage of LVB landed remained around $5 \%$, and the trash fish landed were only those caught during the last day of the voyage. In Mangalore, as in other centres, single-day trawlers brought all the catch to shore and the trash consisted of 30 to $40 \%$ of total catch. On the other hand, multiday trawlers brought the trash in semi-preserved form suitable for fish meal and fertilizer producers. In Mangalore also a strong market chain exist for the LVB and the business is becoming a very prominent economic activity in fisheries of Karnataka. In Mangalore fisheries harbour the increase in trash landing was phenomenal, the trash landing which formed only $3 \%$ $(3,000 \mathrm{t})$ of the trawl landing in 2008 increased to $26 \%$ of the total fish landed $(12,000 t)$ in 2011, the percentage of LVB was 3, 14, 21, 26 in 2008, 2009, 2010 and 2011 respectively. This increase in LVB landing was the result of increased demand from an array of fish meal plants operating all along the Karnataka coast. In Karwar the LVB landed by single day operating trawls was about $42 \%$ (2,310 t) in 2011. In Calicut also there was high demand for the LVB by fishmeal plants and in this centre, LVB landing in 2011 was 12,000 t forming $26 \%$ of the landed catch. In Kochi, at Munambam, the total estimated LVB landed in 2011 was 1,992 $t$ forming $7.2 \%$ of total trawl landings and in Sakthikulangara fisheries harbour the estimated LVB in 2011 was $11 \%$ of the total landing. In Chennai, the observations on LVB was carried out at Kasimedu fisheries harbour and the estimated LVB landing was 13\% $(3,000 \mathrm{t})$ of the total landing in 2008 which increased to $17 \%$ in 2011(5,800 t).In Visakahapatnam, estimated LVB landed show a steady increase from 2\% (705 $\mathrm{t}$ ) of the landing in 2008 to $21 \%(19,000 \mathrm{t})$ in 2011.

\section{Species composition in discarded bycatch}

Analysis of discards from trawlers of from Mangalore showed that 237 species/groups of marine fauna were discarded of which many were juveniles of commercially important species and the rest were adult and juveniles of species, with no market value. Among the commercial species, Saurida tumbil formed the highest percentage $(12.5 \%)$ of discards in terms of weight and $4.7 \%$ in terms of numbers. Juveniles of 14 commercially important species were seen in all the months. The contribution of juveniles of commercial species in discard by number was estimated as $63.7 \%$ and in terms of weight they constituted $37.4 \%$. In a similar study at Calicut, 178 species of fishes and shell fishes were found in the discards. 124 species of fin fishes, comprising mainly low value finfishes and juvenile fishes of commercial value were the main component of discards and it formed $88.6 \%$ by weight. The contribution of crustaceans, molluscs and miscellaneous items was $9.48 \%, 1.73 \%$ and $0.19 \%$, respectively. In earlier studies on the discard composition from trawlers also the juvenile losses were recorded

\section{Species composition in $L V B$}

The demand and price of LVB is determined by the species composition of LVB and finfish dominated LVB had better demand. For assessing the sustainability of marine fisheries production it is imperative to understand the species composition and the juvenile composition of the fishes in the LVB. The species composition of the fishes from different centers is given in Table 1. The species composition of LVB 

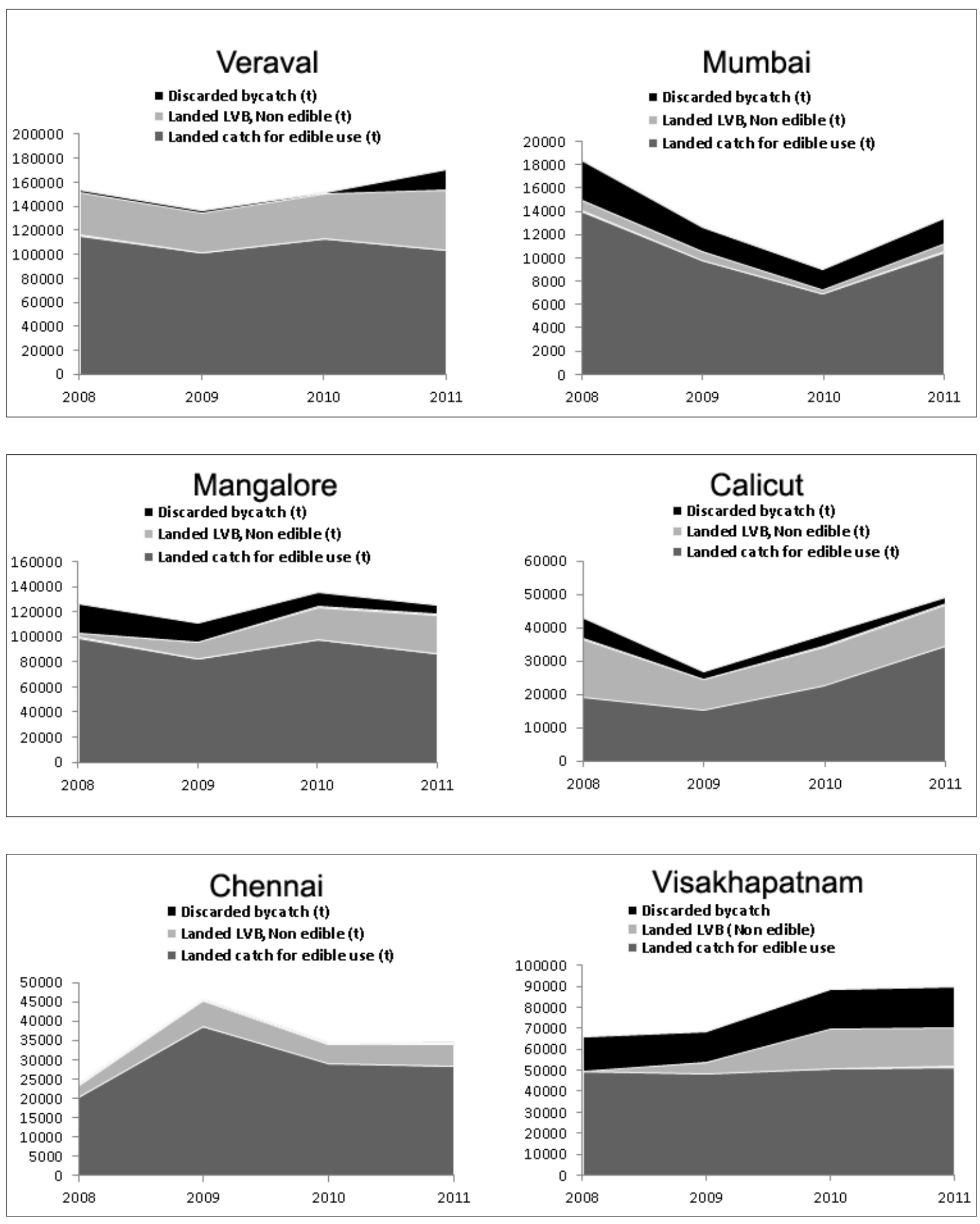

Fig.4. The trawl catch and landing pattern of edible catch, non edible LVB and discarded bycatch at different trawl centres of Indian coast. 
in the south west coast of India shows higher percentage of finfishes than those in east coast and that of northwest coast of India.

\section{Demand and utilization of landed LVB}

From the studies, it was understood that the trawler operators decide landing of fishes either in best possible preserved

Table.1. Composition of the Low Value Bycatch (LVB) landed at different centres (2011).

\begin{tabular}{|c|c|c|}
\hline Centres & No. of genera/species in LVB & Majour species with their percentage in LVB \\
\hline Veraval & 41 species of finfishes, 13 species of crustaceans and 3 species of molluscs & $\begin{array}{l}\text { Acetes indicus, } 18.04 \\
\text { Lagocephalus inermis,6.76 } \\
\text { Epinephelus diacanthus, } 5.54 \\
\text { Charybdis feriata, } 4.94 \\
\text { Trichiurus lepturus, } 4.83 \\
\text { Plotosus lineatus } 4.04 \\
\text { Loligo duvauceli, } 3.37 \\
\text { Exhippolys mataensirostris,3.37 } \\
\text { Apogon sp., } 3.30 \\
\text { Metapenaeus kutchensis, } 3.10 \\
\text { Metapenaeopsis stridulans,2.56 } \\
\text { Solenocera crassicornis, } 2.45 \\
\text { Johnius spp.,2.38 } \\
\text { Decapterus russelli,2.26 }\end{array}$ \\
\hline Mumbai & 51 species of finfishes, 20 species of crustaceans and 11 species of molluscs & $\begin{array}{l}\text { Oratosquilla nepa,20.49 } \\
\text { Cyanoglossus arel,9.06 } \\
\text { Coilia dussumieri, } 7.26 \\
\text { Charybdis callinasa,5.09 } \\
\text { Parapenaeopsis stylifera,4.24 } \\
\text { Trypauchen vagina,3.58 } \\
\text { Apogon sp,3.53 } \\
\text { Otolithes cuvieri,3.45 } \\
\text { Eupleurogrammus muticus, } 3.18 \\
\text { Johnius vogleri,2.94 } \\
\text { Mene maculata,2.41 } \\
\text { Epinephelus diacanthus, } 2.40 \\
\text { Lactarius lactarius,2.36 } \\
\text { Thryssa mystax, } 2.19\end{array}$ \\
\hline Karwar & 57 species of finfishes, 10 species of crustaceans and 10 species of molluscs & $\begin{array}{l}\text { Oratosquilla nepa, } 41.1 \\
\text { Sardinella longiceps,7.7 } \\
\text { Trichiurus lepturus, } 7.7 \\
\text { Star fish, } 7.3 \\
\text { Bivalves, } 6.3 \\
\text { Lagocephalus inermis, } 3.3 \\
\text { Nemipterus japonicas, } 3.2 \\
\text { Charybdis cruciata, } 3.1 \\
\text { Gastropods, } 3.1 \\
\text { Cynoglosus macrostoma, } 1.4 \\
\text { Sepia pharaonis, } 1.3 \\
\text { Sea urchin, } 1.3\end{array}$ \\
\hline Mangalore & 95 species of finfishes, 27 species of crustaceans and 20 species of molluscs. & $\begin{array}{l}\text { Lagocephalus inermis, } 12.80 \\
\text { Saurida spp., } 11.70 \\
\text { Decapterus sp., } 10.63 \\
\text { Sardinella longiceps, } 8.59 \\
\text { Nemipterus spp., } 8.56 \\
\text { Lesser sardines, } 5.93 \\
\text { Platycephalus sp., } 4.06 \\
\text { Alepes sp., } 3.88 \\
\text { Rastrelliger kanagurta } 3.64 \\
\text { Dussumieria acuta } 3.49 \\
\text { Trichiurus lepturus } 3.41 \\
\text { Thryssa sp., } 3.25 \\
\text { Eel 2.46 } \\
\text { Leiognathus spp., } 2.21 \\
\text { Charybdis spp.,1.79 } \\
\text { Cynoglossus macrosoma,1.64 } \\
\text { Oratosquilla nepa, } 1.56 \\
\text { Other prawns, } 1.32 \\
\text { Fistularia petimba, } 1.31\end{array}$ \\
\hline
\end{tabular}


Decapterus sp., 8.7

Saurida tumbil 8.2

Lagocephalus inermis 5.3

Thryssa sp., 4.9

Platycephalus sp., 4.8

Trichiurus sp., 4.5

Opistopterus tardoore , 4.1

Caranx sp., 4.0

Dusumeria acuta 3.6

Johnius sina, 2.5

Nemipterus randali, 2.2

Stolephorus sp., 2.1

Saurida undosquamis, 2.1

Nemipterus japonicus, 1.8

Oratosquilla nepa, 1.7

Sardinella longiceps, 1.6

Oratosquilla nepa, 25.2

Babylonia sp., 11

Charybdis lucifera, 6

Bursa sp., 6

Sardinella spp., 3.2

Kochi

25 species of finfishes, 16 species of crustaceans and 15 species of molluscs

Cynoglossus sp 2.3

Lagocephalus inermis, 2.8

Leiognathus sp., 2.8

Johnius spp., 2.1

Arius sp., 1.8

Otolithus sp 1.3

Docleaovis $\mathrm{sp}, 12$

Oratosquilla nepa 8

Sardinella spp. , 8.2

Tibia sp., 8.5

Sciaenids, 7.6

Babylonia sp., 7.3

Bursa sp., 6.8

Cynoglossus sp., 6.2

Leiognathus sp., 5.8

Thryssa mystax, 5

Lagocephalus inermis, 4.2

Parapenaeopsis stylifera, 2

Crossorhombus azureus, 4.56

Upeneus taeniopterus, 3.38

Upeneus sundaicus, 2.82

Grammoplites scaber,2.72

Oratosquilla nepa,2.61

Thryssa mystax, 2.57

Sardinella gibbosa, 2.46

Eubleekeria splendens, 2.1

Secutor insidiator, 2.0

Petrarctus rugosus, 1.43

Portunus sanguinolentus, 1.35

Turritella sp., 1.29

Harpiosquilla harpax, 1.23

Metapenaeopsis stridulans, 1.16

Leiognathus bindus, 11.04,

Muraenosox sp., 7.51

Charybdis (Goniohellenus) hoplites, 6.64

Oratosquilla spp., 5.98

Charybdis (Goniohellenus) truncata, 5.52

Apogon spp., 5.34

Upeneus vittatus, 4.78

Upeneus sulphureus, 4.1

Tetradon sp., 3.44

Equulites leuciscus 2.31

Priacanthus spp., 2.28

Sardinella spp., 2.16

Platycephalus spp., 2.03

Trichiurus spp., 1.93

Thryssa spp., 1.8 
form (keeping in frozen state) or in semi-preserved state (by sprinkling ice over the catch to reduce deterioration) according to the value realization that they get in the landing centre. The fishes with less preservation or no preservation are landed as trash. Increasing demand from fish meal plants and fertilizer producers has improved the value realization for the landed LVB. In Veraval and Mumbai the LVB rate per $\mathrm{kg}$ increased from Rs. 2 (2008) to Rs. 4 in 2011. In Mangalore the average rate for LVB increased from Rs. 4 to Rs.9 in 2008-2011. In Calicut also similar price increase in trash was noticed. On the east coast at Chennai the price for LVB increased from an average of Rs. 4 in 2008 to Rs. 7 in 2011 whereas in Visakhapatnam the increase was marginal from Rs. 2 to Rs. 3 in four years.

It is observed that even though the highest annual LVB landing was in Veraval $(50,000 \mathrm{t})$ the value realization was the highest in Mangalore (Rs. 280 million) (Fig.5). The composition of the LVB determined the price for LVB. Fish dominated trash was in much demand and in Mangalore, multiday trawlers brought LVB in a semi-preserved form, as it fetched a rate as high as Rs.12/kg. This is mainly used for fish meal preparation. In Mangalore, single-day operating vessels landed trash dominated by mollusc and crustacean for which the highest price realized was only Rs. $4 / \mathrm{kg}$, which is mainly used for drying for low cost fish meal. The composition of finfishes in the LVB was highest in Mangalore and Calicut (85 to 90\%) whereas in Veraval, Mumbai, Chennai and Visakhapatnam the finfish composition in LVB remained below $65 \%$ throughout the period of observation (Fig. 5).

\section{Discussion}

Bycatch and discarding from trawlers is of great concern worldwide and extensive studies are carried out to understand

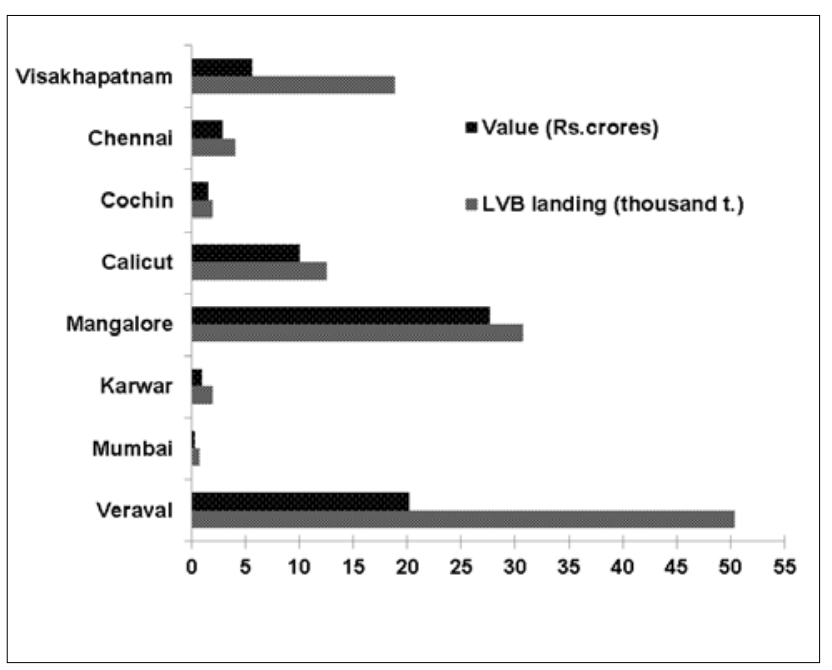

Fig.5. The LVB landings and value realization in 2011 its impact on the structure of marine communities and/or ecosystems (Alverson et al., 1994). Bhoopendranath (2007) reviewed the studies carried out on the trawl bycatch along the Indian coast. There were many attempts to estimate the discards from trawlers in different parts of the country at different occasions. Although region based estimates are reported, a comprehensive study on the trawl bycatch/discards from Indian trawl fishery was not carried out. Along the Visakhapatnam coast, Gordon (1991) estimated that 25-30\% of discards from trawlers were comprised of juvenile shrimps. Later Rao (1998) re-estimated the quantity of the discards from trawler fleet based at Visakhapatnam and reported the total trawl landing of about 40,410 tonnes of which $80 \%$ is discarded. Bhathal (2005) during her historical reconstruction of Indian marine fisheries catches (1950-2000) observed that discards from Indian fisheries is having a heavy impact on the marine trophic structure. The present study analysed the ecosystem damages due to discards at the species level by analyzing discard composition. The growth overfishing was indicated in the present study in many species and there were a number of commercial species are being discarded or treated as LVB because the size caught was far below its marketable size. Menon (1996) has estimated that 6,200 $t$ of juvenile fish and prawns were discarded back into the sea by trawlers during 1980-84 along the southwest coast of India. Sujatha (1995) identified 228 species from the discarded bycatch at Visakhapatanam and on the west coast, Zacharia et al. (2006) recorded 53 species of fishes (23 always discarded), 12 crustaceans (6 always discarded), 27 molluscs ( 22 always discarded) and 7 other invertebrates (always discarded) from multiday trawlers operated along the Karnataka and Dineshbabu et al (2010) identified the spatial distribution of 198 species, (116 species of finfishes, 31 species of gastropods, 4 species of bivalves, 7 species of cephalopods, 13 species of shrimps, 3 species of stomatopods 21 species of crabs, 3 species of lobsters and other fauna) from discards off trawling grounds of Karnataka. As in the case of discards the composition of LVB also was topic of research in different parts of the country. Luther and Sastry (1993) reported that the bulk of the LVB landings in different maritime states comprised of juveniles. Juvenile composition of the LVB landed by trawlers were studied at Visakhaptnam in late eighties and found that LVB from trawlers was constituted by 85 species and more than $50 \%$ of LVB were immature fishes (Sivasubramanyam, 1990). The study cautioned that juvenile fish landing as LVB could affect the stock and consequently the fishery economy of the commercial fishery of succeeding years. Zacharia et al. (2006) and Kumar and Deepthi (2006) have also highlighted the implications of trawl bycatch on marine ecosystem along south west coast of India. Identification of critical fishing ground in terms of juvenile abundance and biodiversity should be carried out and the practice of seasonal and spatial closure 
of trawl fishery should be implemented in these critical fishing grounds. Preliminary experiments of GIS based studies in trawl fisheries of Karnataka (Dineshbabu et.al., 2012) have shown the prospects of identification of critical fishing ground and also the prospects of spatial restriction and spatial allocation of trawler effort in marine fisheries resource conservation and management through spatio-temporal studies.

Apart from the biological loss, discards form an unknown factor for stock assessments of fishery resources. Stock assessment, which forms the backbone of fisheries management policies, is generally carried out based on the landing data by ignoring the volume of discards, resulting in underestimation of year class strength (Casey, 1993; Dingsor, 2001). Kurup et al. (2004) carried out a detailed study on the trawl bycatch of Kerala and suggested that the discarded quantity also need to be added to the landing data to arrive at reasonable estimates of the total removal of fishes from the sea by trawlers. The discarded quantity if added to the total landings, the estimated total fish landing from Kerala worked out to be 7.63 lakh $\mathrm{t}$, almost reaching the potential stock level. In the present study, it was observed that in Indian trawl fishery, around $90 \%$ of the fish caught is landed and 10\% discarded and this correction had to be incorporated with the landing for making yield based projection in fishery management. By substituting this figure to all India trawl landing of $2011(20,27,000 \mathrm{t})$ the total trawl catch in 2011 is estimated to be around 22 million t. Reducing discards in trawl fisheries by improving its utilization was one of the major objective for Food and Agriculture Organization (Alverson et al., 1994). In India, it is observed that in all major landing centers the discards from trawlers declined considerably and the LVB landing increased.This is a positive consequence as far as the objective of FAO is concerned. All India average percentage of landed LVB showed gradual increase from $14 \%$ in 2008 to $25 \%$ in 2011 . In Asia, there has been considerable growth in aquaculture in recent years and the demand for trash in fish meal plants in India has also increased to a large extent. The discards from trawlers have been found to reducing but trash landing was on the increase in all the centres. Chandrapal (2005) estimated that that about $15 \%$ of the total Indian fish production goes for fish meal production. He warned that the requirement of fish for the production of aquaculture feed is going to increase in coming years giving more pressure on marine ecosystem and also threatening the food security. In the present study, it is seen that in the percentage of sardines and low valued fishes in LVB has been on the increase. The value realized for the landed LVB in some period goes up to Rs. 16 per $\mathrm{kg}$ (in Mangalore), which is more than the price realized for those landed in fresh form. In 2011, in Mangalore alone, 2,600 t of oil sardines, 1,800 $t$ of lesser sardines and more than 32,000 t. of Decapterus spp. were landed as LVB, mainly because the landing of these fishes as trash is economically more beneficial than bringing it in preserved form for edible purpose. If this situation is allowed to continue, it may cause serious threat to food security of the coastal population, who thrives on these low valued fishes for meeting their protein requirement.

Trawling has acquired the status of an industry with incorporation of the state of art technological advancements, in terms of more speed, higher capacity, efficient navigational/ fish finding equipment etc. The high investment and fluctuating returns lead to high competition in the industry overlooking the sustainability of the fisheries. There is a considerable reduction in percentage of discards by trawlers operated along Indian EEZ and the discard percent in Indian trawl fisheries in 2011 was less than 10\% and In many major fishing harbours the percentage was less than $5 \%$. Fish protein landed in any form is having a very high demand in fish meal plants especially the feed industries and this demand in turn encourage the trawler operators to land more and more trash fishes. Looking at the trend of trawl landing during 20082012 , it was quite evident that though total landing increased over the period of time, there was no substantial increase in the edible portion of the trawl landing whereas trend is almost steady or slightly decreasing. The increase in total landings is contributed mainly by landing of non-edible LVB. The trawlers equipped with high storage capacity (to the tune of $40 \mathrm{t}$ ) and high speed (>450 hp) are intensively trawling to catch as much as possible without any concern over the size of fish or the species of fish or the future concerns about the fishery. This practice is causing heavy damage to the marine ecosystem and by continuous landing of juvenile fishes, the sustainability of the fisheries production is under serious threat. Since trawl fishery is the backbone of Indian marine fisheries production and bycatch by the trawlers in tropical multi-species scenario is unavoidable, spatio-temporal and effort allocation coupled with effort restrictions based on the identification of critical fishing ground can bring down the damages to the ecosystem by reducing bycatch considerably.

\section{Acknowledgements}

The authors are thankful to Dr. G. Syda Rao, Director, C. M. F. R. Institute, Cochin for his constant encouragement, support and valuable suggestions. The co-operation and help provided by the fishing community in major fishing harbours of India viz. Veraval, Mumbai, Karwar, Mangalore, Calicut, Kochi, Sakhthikulangara, Chennai and Visakhapatnam is acknowledged with gratitude. The technical assistance provided by the technical staff of CMFRI at Veraval, Mumbai, Karwar, Mangalore, Calicut, Kochi, Chennai and Visakhapatnam are also thankfully acknowledged. 


\section{References}

Alverson, D. L., M. H. Freeberg, J. G. Pope and S. A. Murawski. 1994. A global assessment of fisheries bycatch and discard. FAO Fish. Tech. Pap. 339, 233 pp

Aswathi, N., R. Sathyadhas, R. Narayana Kumar and Shyam, S. Salim. 2011. Marketing and utilization of marine bycatch:problems and prospects. J. Fish. Econ. Dev. XII (2): $1-8$

Bhathal, B. 2005. Historical reconstruction of Indian marine fisheries catches, 19502000, as a basis for testing the 'Marine Trophic Index'. Fisheries Center Research Report 13(5): $122 \mathrm{pp}$.

Boopendranath, M. R. 2007. Possibilities of bycatch reduction from Trawlers in India. In: Indian fisheries an progressive outlook. Central Marine Fisheries Research Institute, Kochi, 12-29

Casey J. 1993. Estimating discards using selectivity data: the effects of including discard data in assessments of demersal fisheries in the Irish Sea. J. Northwest Atl. Fish. Soc. 19: 91-102.

Chandrapal, G. D. 2005. Status of trash fish utilization and fish feed requirements in aquaculture-India. Paper presented at the regional workshop on low value and trash fish in the Asia-Pacific region. Hanoi, Vietnam 7-9 June 2005.

Costa, M. E, K. Erzini and T. C. Borges. 2008. Bycatch of crustacean and fish bottom trawl fisheries from southern Portugal (Algarve) Sci. Mar., Barcelona (Spain) 72(4): 801-814

Devaraj, M and E. Vivekanandan. 1999. Marine capture fisheries of India: Challenges and opportunities, Current Science, 76 (3): 314-332.

Dineshbabu, A. P, SujithaThomas and E. V Radhakrishnan. 2010. Bycatch from Trawlers with special reference to Its Impact on Commercial Fishery, off Mangalore. In: Meenakumari B., Boopendranath, M. R. Edwin, Leela; Sankar, T. V.; Nikita Gopal And Niran George (Eds) Coastal Fishery Resources of India - Conservation and Sustainable Utilisation. Central Institute of Fishery Technology, Kochi, 2010: 327334.

Dineshbabu, A.P, Sujitha Thomas and E. V., Radhakrishnan. 2012. Spatio- temporal analysis and impact assessment of trawl bycatch of Kanataka to suggest operation based fishery management options.Indian J. Fish 59(2): 27-38.

Dingsor, G.E. 2001. Estimation of discards in the commercial trawl fishery for Northeast Arctic cod (Gadusmorhua L.) and some effects on assessment. Department of Fisheries and Marine Biology. Bergen, University of Bergen, 86p.

FAO. 2010. Catch concepts: Diagrammatic Presentation, FAO Yearbook: Fishery and aquaculture statistics 2008. FAO, Rome, 96p.

Gordon, A. 1991. Bycatch from Indian trawlers in Bay of Bengal, Bay of Bengal program BOBP/WP/68, 29p.
Jennings, S., and M. J, Kaiser. 1998. The effect of fishing on marine ecosystems. Adv. Mar. Biol.,34: 201-352.

Kumar, B. A and G. R., Deepthi 2006. Trawling and by-catch: Implications on marine ecosystem, Curr. Sci., 90 (7): 922-931.

Kurup, M, P., Premlal., Joice, V. Thomas and Vijay Anand. 2004. Bottom trawl discards along Kerala coast : a case study, Indian J Fish, 45:199-107.

Luther, $G$ and Y. A. Sastry. 1993. Occurrence of spawners, juveniles, and young fish in relation to the fishery seasons of some major fishery resources of India. Mar. Fish. Infor. Serv. T\& E Ser. No.122: 1-8.

Menon, N. G. 1996. Impact of bottom trawling on exploited resources. In: Menon, N G, Pillai CSG. (eds.) Marine biodiversity conservation and management. Central Marine Fisheries Research Institute, Cochin, 82-97pp.

Rao, G.S. 1998. Bycatch discards of trawlers of Visakhapatnam In: Advances and priorities in fisheries Technology, Society of fisheries technologists, India Cochin 501-505.

Simon Funge Smith, Erick Lindebo and Derek Staples.,2005.Asian Fisheries today-The production and use of low value trash fish from marine fisheries of the Asia Pacific region, Asia-Pacific fishery commission, Food and Agriculture Organization of the United Nations, RAP Publication 16, 38p.

Sivasubramaniam. 1990. Biological aspects of shrimp trawl bycatch. Bay of Bengal News Issue, 40: 8-10.

Srinath M, Somy Kuriakose and K. G. Mini, 2005. Methodology for the estimation of marine fish landings in India. CMFRI, Special Publication. 86: 57p.

Srinath, M., 2003. An Appraisal of the Exploited Marine Fishery Resources of India.In: Status of Exploited Marine Fishery Resources of India. Mohan Joseph, M and Jayaprakash, A A(eds.) CMFRI, Cochin, 1-17pp.

Sujatha, K. 1995.Finfish constituents of trawl by-catch off Visakhapatnam, Fish. Technol. 32(1): 56-60.

Van Beek F. A.1998. Discarding in the Dutch beam trawl fishery.International Council for the Exploration of the Sea. Theme Session on Fisheries Assessment Methods; ICES CM 1998/BB,5.

Zacharia, P. U., P. K. Krishnakumar, C. Muthiah, Anoop, A. Krishnan and Ravindra, N. Durgekar. 2006. Assessment of bycatch and discards associated with bottom trawling along Karnataka cast, India. Sustain Fish (2006) Kurup B M and Ravindran K (Eds.) School of Industrial Fisheries, CUSAT, Cochin 682016, 434-445. 